\title{
A ELECCIÓN DE PADRIÑOS DE BAUTISMO EN PORTOMARÍN (SÉCULOS XVII-XIX)*
}

\author{
TAMARA GONZÁlEz LÓPEZ \\ Universidade da Coruña \\ ORCID ID: http://orcid.org/0000-0003-3778-1931
}

* Traballo realizado no marco do Proxecto de Investigación "El monte comunal en Galicia desde comienzos de la edad moderna a la actualidad: de soporte de un viejo complejo agrario a recurso medioambiental y patrimonio paisajístico" HAR2014-52667-R, financiado pola Axencia Estatal de Investigación e Fondos Feder da Unión Europea.

Copyright: (C) 2021 CSIC. La edición electrónica de esta revista se distribuye bajo los términos de una licencia de uso y distribución Creative Commons Reconocimiento 4.0 Internacional (CC BY 4.0).

Cómo citar/Citation: Tamara GonzÁlez LóPEZ, "A elección de padriños de bautismo en Portomarín (séculos XVII-XIX)”, Cuadernos de Estudios Gallegos, 68, núm. 134 (2021), págs. 241-266, https://doi.org/10.3989/ceg.2021.134.08 


\section{A ELECCIÓN DE PADRIÑOS DE BAUTISMO EN PORTOMARÍN (SÉCULOS XVII-XIX)}

\section{RESUMO}

A vila de Portomarín foi, durante toda a Idade Moderna, un núcleo de importancia no centro da diocese de Lugo. No presente texto abórdase a elección que os proxenitores residentes na devandita vila fixeron para os padriños de seus fillos. O estudo das vilas que estruturaban o interior lucense resulta fundamental, xa que as novas tendencias e prácticas de apadriñamento chegaron primeiro aos núcleos urbanos, dende onde se expandiron ao territorio rural circundante.

Entre os numerosos factores que se podían ter en conta, optamos por analizar a incidencia de tres: veciñanza, parentesco e posición social; análise que realizamos para o período comprendido entre mediados do século XVII e finais do século XIX. A través deles, constátase o coidadosa e intencionada que era a elección de padriños, que respondía ao contexto no que se atopaban os pais.

Palabras ClaVE: Apadriñamento; Idade Moderna; Portomarín; Lugo; Redes sociais.

\section{LA ELECCIÓN DE PADRINOS DE BAUTISMO EN PORTOMARÍN (SIGLOS XVII-XIX)}

\section{RESUMEN}

La villa de Portomarín ha sido, durante toda la Edad Moderna, un núcleo de cierta importancia en el centro de la diócesis de Lugo. En el presente texto, se aborda la elección que los padres residentes en dicha villa hicieron para los padrinos de sus hijos. El estudio de las villas que estructuraban el interior lucense resulta fundamental, puesto que las nuevas tendencias en lo relativo al padrinazgo llegaron primeramente a los núcleos urbanos, desde donde se expandieron al territorio rural circundante.

Entre los numerosos factores que se podrían tener en cuenta, hemos optado por analizar la incidencia que de tres de ellos: vecindad, parentesco y posición social; análisis que realizamos para el período comprendido entre mediados del siglo XVII y finales del siglo XIX. A través de ellos, se constata lo cuidadosa y reflexiva que era dicha elección respondiendo a las condiciones en las que se hallaban los padres.

Palabras ClaVe: Padrinazgo; Edad Moderna; Portomarín; Lugo; Redes Sociales.

\section{THE CHOICE OF BAPTISM GODPARENTS IN PORTOMARIN $\left(17^{\mathrm{TH}}-19^{\mathrm{TH}}\right.$ CENTURIES)}

\section{ABSTRACT}

During the entire Modern Age, the town of Portomarín has been a relatively important centre in the middle of the diocese of Lugo. In the present text, we look into the choices that parents made for the godparents of their children. Analysing the towns which comprise the interior of the diocese of Lugo is fundamental, because the new tendencies regarding spiritual kinship reached urban locations first, from where the expanded to the surrounding rural territory.

Among the many factors that could be considered, we have analysed the influence of three: neighbourhood ties, kinship, and social position, for the period between the middle of the $17^{\text {th }}$ century and the end of the $19^{\text {th }}$ century. During this period, we can see how careful and reflective this choice was, depending on the parents' situation.

KEY WORDS: Spiritual Kinship; Modern Age; Portomarín; Lugo; Social Networks. 
Recibido/Received: 10/04/2020

Aceptado/Accepted: 25/10/2020

$\mathrm{N}$ os últimos anos tense desenvolto unha corrente de estudo centrada nas prácticas de apadriñamento bautismal. $\mathrm{O}$ parentesco espiritual que se creaba entre bautizado, proxenitores e padriños constituía un lazo de longa duración que se inscribía nas redes sociais da familia. En Europa, a análise destas redes tivo un gran pulo dende Italia e Francia, dende onde se estendeu a outras áreas e calou con éxito como obxecto de estudo ${ }^{1}$.

Para España, os estudos sobre este tema son escasos, aínda que non se poden obviar as achegas sobre continxentes específicos, como mouriscos ou escravos, de Francisco Chacón, ou o achegamento máis amplo de Ansón Calvo; sen esquecer a abordaxe máis teórica de Pitt-Rivers ${ }^{2}$. Pero foi, en épocas recentes, cando unha visión máis sistemática, que segue a corrente italiana, traspasou á Península da man de Ofelia Rey Castelao, no norte, e Antonio Irigoyen, no sur peninsular ${ }^{3}$. Actualmente, son diversas as zonas estudadas que

\footnotetext{
${ }^{1}$ Como mostra do pulo que adquiriu o apadriñamento e o bautismo como obxecto de estudo véxanse as múltiples aportacións procedentes de distintos países contidos en Guido Alfani, Philippe CASTAGNeTti e Vincent Gourdon (eds.), Baptiser: pratique sacramentelle, pratique sociale (XVIe-XXe siècle), SaintÉtienne, Université de Saint-Étienne, 2009; Guido Alfani e Vincent Gourdon (eds.), Spiritual Kinship in Europe, 1500-1900, London, Palgrave Macmillan, 2012; Guido ALFANI, Vincent GouRDON e Isabelle RoBIN (eds.), Le parrainage en Europe et en Amérique. Pratiques de longue durée, XVIe-XXIe siècle, Bruxelles, Peter Lang, 2015.

${ }^{2}$ Francisco CHACÓN JiMÉNEZ, "Identidad y parentescos ficticios en la organización social castellana de los siglos XVI y XVII: el ejemplo de Murcia”, en Agustín Redondo (ed.), Les parentés fictives en Espagne (XVIe-XVIIe siècles), Paris, Publications de la Sorbonne, 1988, páxs. 37-50; María del Carmen Ansón Calvo, "Sociología del bautismo en el siglo XVII", Cuadernos de investigación: Geografia e historia, 3 (1977), páxs. 69-90; Julián PitT-Rivers, "L'elecció del padrí i l'elecció del nom: introducció a l'estudi del cas", Quaderns de l'Institut Català d'Antropologia, 5 (1984), páxs. 85-94.

${ }^{3}$ Ofelia Rey CAStelao e Baudilio Barreiro Mallón, "Apadrinar a un pobre en la diócesis de Santiago de Compostela, siglos XVII-XIX”, en María José Pérez Álvarez e Maria Marta Lobo de Araújo (eds.), La respuesta social a la pobreza en la Península Ibérica durante la Edad Moderna, León, Servicio de Publicaciones de la Universidad de León, 2014, páxs. 209-238; Ofelia Rey CastelaO, "De la casa a la pila: hábitos y costumbres de bautismo y padrinazgo en Santiago de Compostela, siglos XVII-XVIII", en Inmaculada Arias de Saavedra Alías e Miguel Luis López Guadalupe Muñoz (eds.), Vida cotidiana en la Monarquía Hispánica: Tiempos y espacios, Granada, Universidad de Granada, 2015, páxs. 195-214; Ofelia Rey CastelaO, "Parrains et marraines en Galice aux XVIe-XIXe siècles: le diocèse de SaintJacques-de-Compostelle", en Guido Alfani, Vincent Gourdon e Isabelle Robin (eds.), Le parrainage en
} 
amosan unha ampla diversidade de prácticas, comportamentos e tendencias no apadriñamento ${ }^{4}$.

Pretendemos, pois, a continuación, tratar de abordar os distintos factores que se valoraban na elección dos padriños, para unha mellor comprensión do que este vínculo entrañaba: modelos de apadriñamento, procedencia social e veciñanza dos padriños, así como o parentesco que os unía aos bautizados tórnanse os piares básicos que empregamos. Centramos o estudo nunha área concreta do interior lucense: a vila de Portomarín, que polas súas características representa un núcleo de interese.

Unha cuestión importante á hora de analizar o apadriñamento é o prazo e momento da selección dos padriños. Aqueles que abordaron esta cuestión divídense entre os que afirmaban que a decisión era posterior ao parto e os que defenden que se producía con anterioridade. Con todo, aínda que puido haber proxenitores precavidos que xa tivesen unha idea ou estratexias determinadas a seguir, os indicios apuntan a unha petición aos padriños posterior ao parto. Isto implica que, segundo a época, tiñan un prazo distinto para facelo que a Igrexa situaba como máximo en oito días 5 . A inicios do século XX, o $81 \%$ dos nenos bautizábanse o propio día ou ao seguinte -en función da hora de nacemento-; un século antes, o $83 \%$ bautizábase ao terceiro día ou posteriores. Canto máis atrás nos situemos, máis tempo se deixaba transcorrer entre nacemento e bautismo, coa consecuente ampliación do prazo para estabelecer unha estratexia.

\footnotetext{
Europ... páxs. 69-98; Antonio IRIGOYEN LóPEZ, "Ecclesiastical godparenthood in Early Modern Murcia", en Guido Alfani e Vincent Gourdon (eds.), Spiritual Kinship..., páxs. 74-95; Mónica GHIRARDi e Antonio IRIGOYEN LÓPEZ, "Sacramento bautismal y padrinazgo de niños huérfanos. Textos eclesiástiscos postridentinos y prácticas en la Córdoba de mediados del siglo XIX”, en Ana Cecilia Aguirre e Esteban Abalo (eds.), Representaciones sobre historia y religiosidad: deshaciendo fronteras, Rosario, Prohistoria Ediciones, 2014, páxs. 129-142.

${ }^{4}$ Entre outros Beatriz CASTRO DíAz, "Familia, apadriñamento e onomástica na bisbarra eumesa: unha aproximación histórico-etnográfica (séculos XVII-XIX)", Cátedra: revista eumesa de estudios, 18 (2011), páxs. 413-474; Héctor Fernando SÁNCHEZ DiEGO, "Patrones y prácticas asociadas al padrinazgo en un entorno rural: el valle de Iguña durante el s. XVII”, Tiempos modernos: Revista Electrónica de Historia Moderna, vol. 8, núm. 29 (2014), páxs. 1-16; Héctor Fernando SÁNCHEz DiEGO, "Padrinazgo bautismal e inserción del foráneo en la Cantabria moderna”, en Juan José Iglesias Rodríguez, Rafael M. Pérez García e Manuel F. Fernández Chaves (eds.), Comercio y cultura en la Edad Moderna, Sevilla, Universidad de Sevilla, 2015, páxs. 1667-1684; Tamara GonZÁLEZ LóPEZ, “Apadriñamento no Arciprestado de Bolaño”, Lucensia: miscelánea de cultura e investigación, vol. 27, núm. 53 (2016), páxs. 87-103; Pamela RuBio VelAsco, "La naturaleza del padrinazgo en la comarca de Ciudad Rodrigo (Salamanca) a lo largo del siglo XVIII", Tiempos modernos: Revista Electrónica de Historia Moderna, vol. 9, núm. 36 (2018).

5 Matías de Moratinos y Santos, Constituciones Synodales del Obispado de Lugo. Compiladas, hechas y promulgadas por el Ilmo. Sr. D. Matías de Moratinos, Madrid, Imp. Ioseph Fernández de Buendía, 1675, Lib. III, Tít. XIV.
} 


\section{A VILA DE Portomarín NO SÉCULO XVIII}

A parroquia de san Nicolás ou san Xoán de Portomarín constitúe, xunto coa parroquia de san Pedro, a vila de Portomarín. O señorío xurisdicional de cada unha estaba en mans diferentes, ao pertencer san Nicolás á Encomenda de Portomarín, da orden de San Xoán de Xerusalén, mentres que a xurisdición de san Pedro ostentábaa o Marques de Bóveda ${ }^{6}$. De orixe medieval, a evolución e o crecemento de ambas freguesías foi diferente. A mediados do século XVIII, san Pedro non acadaba as trinta familias fronte ás cento trinta e tres de san Nicolás ${ }^{7}$. Dado o seu maior dinamismo demográfico que permite realizar comparacións de máis variables, a análise do apadriñamento céntrase na freguesía de san Nicolás.

Seis familias de san Nicolás gozaban da consideración de nobres que, ademais da exención de impostos, podía outorgarlles un papel destacado como padriños $^{8}$. A media de residentes nas casas destes fidalgos era de 6,83, moi superior ás 4,71 persoas que residían nas casas dos labregos. Agora ben, a cifra de residentes dos fidalgos rebaixábase a 4,33 ao non contabilizar aos criados; distinción importante, xa que, malia que os criados formaban parte da casa, á hora de optar pola fidalguía como padriños, estes criados carecían da consideración de selo 9 . Con todo, non se debe desprezar este sector, posto que podía constituír unha vía de contacto indirecto coa fidalguía. Semellante situación acontece no 18\% dos fogares de labradores que contaban con criados na parroquia ${ }^{10}$.

A dedicación económica principal era a agricultura, especialmente o cultivo do centeo, para o que se reservaba o $85,22 \%$ do terreo cultivado, ao que se engadía o 7,68\% que se dedicaba á vide ${ }^{11}$. Amais da agricultura, o 19,8\% dos cabezas de casa exercían outro oficio ou percibían ingresos por outra dedicación ${ }^{12}$. Tras

\footnotetext{
${ }^{6}$ Rubén Castro Redondo, Cartografia digital de Galicia en 1753. Jurisdicciones, provincias y Reino, Santiago de Compostela, Andavira, 2019, páxs. 173-174. As Encomendas de Portomarín e Quiroga foron as máis importantes de Galicia representando dous terzos da poboación e o territorio; malia iso, o seu peso total foi escaso, xa que as Ordes Militares non representaron máis do $2 \%$ da poboación e o territorio nas provincias de Ourense e Lugo. Antonio EIRAs RoEL, "El régimen señorial en Galicia a finales de la Edad Moderna: evaluación”, Obradoiro de Historia Moderna, 6 (1997), páx. 17.

7 Antonio Domínguez Ortiz,Concepción Camarero e Jesús Campos (eds.), Vecindario de Ensenada 1759, Madrid, Centro de Gestión Catastral y Cooperación Tributaria, 1991, páxs. 312-313.

${ }^{8}$ Só seis familias foron rexistradas como nobres, pero eran oito as que amosan o seu dereito ao uso do tratamento 'don'.

9 Isidro Dubert GARCÍA, Los comportamientos de la familia urbana en la Galicia del Antiguo Régimen: el ejemplo de Santiago de Compostela en el siglo XVIII, Santiago de Compostela, Universidade de Santiago de Compostela, 1987, páx. 49.

10 Arquivo Histórico Provincial de Lugo (en adiante AHPLu), Catastro da Ensenada, Personal de Legos, 10638-04.

11 Archivo General de Simancas (en adiante AGS), Catastro de la Ensenada, Respuestas Generales, Leg. 183, fols. 737-738.

12 Os cabezas de casa da parroquia de San Nicolás de Portomarín foron rexistrados no Catastro da En-
} 
os seis varóns que formaban parte da xustiza da vila ostentando os cargos de alcaldes ordinarios ou alguacís, destacan os tres zapateiros e os dous xastres. Determinadas ocupacións laborais evidencian o carácter de centro comarcal da vila e de zona de tránsito tales como dous verederos, un tratante ou o dono dun mesón; o perfil laboral da vila complementábase cos residentes en san Pedro, onde destacan dous tendeiros, outros dous zapateiros e un carcereiro ${ }^{13}$.

A situación estratéxica de Portomarín na ribeira do Miño e no camiño cara as cidades de Santiago de Compostela e Lugo fai que se trate dun núcleo cunha especial relevancia polo tránsito de persoas que discorría por ela. En varios quilómetros ao redor, aqueles que residían nunha beira do río debían acudir á vila, onde existía unha ponte, para cruzar á outra beira. Supoñía, por tanto, un punto de concentración e circulación de poboación flotante e emigrada polas posibilidades económicas derivadas.

No tocante á presente análise, representa unha canle de chegada e difusión de novas modas nas prácticas de bautismo. A súa chegada non implicou a súa adquisición, senón que fronte modas que rapidamente foron adaptadas á realidade portomariñense, outras atopáronse coa reticencia da poboación.

\section{OS MODELOS DE APADRIÑAMENTO}

Para analizar a figura dos padriños é preciso deterse nos modelos de apadriñamento empregados, pois o distinto número e características de cada un determinaba a densidade das redes sociais que se creaban. Amais, ao analizar a evolución temporal dos modelos, pódese entrever o seu calendario de chegada e aceptación social, xunto coa incidencia que acadou e o rol difusor da vila cara as áreas rurais da contorna.

Os rexistros máis antigos de san Nicolás de Portomarín, de mediados do século XVII, indican o predominio do modelo de parella -home e muller- e a ausencia total dos modelos múltiples que o Concilio de Trento vetara. Este Concilio (1545-1563) representou un punto de inflexión no tocante aos modelos de apadriñamento ao prohibir que máis de dúas persoas de distinto sexo apadriñasen simultaneamente. Os estudos de Guido Alfani amosaron como en Italia e, de xeito semellante, noutras áreas europeas convivían diferentes modelos e prác-

seada como fidalgos o 4,6\%, labradores o 78,9\%, con maior dedicación a outros oficios o 9,2\% e o 7,3\% mulleres solteiras ou viúvas. Se contabilizamos as dúas parroquias da vila, o volume de fidalgos ascende ao $5,3 \%$, o dos labradores descende ao $77,4 \%$, outros oficios ao $9,8 \%$ e as mulleres xefas de familia representaban o $7,5 \%$.

${ }_{13}$ AHPLu, Catastro da Ensenada, Personal de Legos, 10201-14. 
ticas que ían dende unha soa persoa apadriñando ata máis dunha ducia ${ }^{14}$. Dos seis modelos sistematizados por Alfani, o Concilio só permitiu dous: o citado modelo de parella e o modelo de padriño individual. Realmente, a súa pretensión era permitir só unha persoa como padriño de cada bautizado, pero optaron por admitir o modelo de parella polas reticencias e a oposición manifestada ás novas medidas nas zonas de predominio de modelos múltiples. O parentesco espiritual que se creaba no bautismo constituía unha estratexia de creación de redes sociais que gozaba de saúde no século XVI; a poboación e, incluso, unha parte do clero opúxose aos cambios porque representaba unha alteración dos costumes sociais e unha redución drástica do número de persoas coas que podían establecer relacións.

En Portomarín, o modelo de parella foi o predominante dende que se teñen rexistros ata o século XX, pero tivo que compartir espazo co modelo de padriño individual, que apareceu na vila a finais do século XVII ${ }^{15}$. Neste modelo no que só unha persoa se vinculaba espiritualmente co bautizado e coa súa familia e se facía cargo das demais obrigas derivadas do apadriñamento, a persoa seleccionada podía tratarse tanto dun varón como dunha muller. A Igrexa non alentou á poboación a escoller prioritariamente a un sexo como padriño, pero si tratou de fomentar este modelo fronte ao de parella por mor das restricións matrimoniais que estabelecía o parentesco espiritual creado entre cada padriño cos pais e co afillado ${ }^{16}$.

A irrupción do modelo individual nesta área ten unha cronoloxía levemente tardía respecto a outras zonas lucenses e, especialmente, en comparación coa Galicia atlántica. Namentres xa se atopan casos deste modelo na primeira metade do século XVII en comarcas como Chantada ou os Ancares, na vila de Portomarín non tivo presenza ata os anos finais do século ${ }^{17}$. O apoxeo deste modelo foi no século XIX, cando foi empregado para apadriñar ao $38 \%$ dos cativos. Esta tendencia si encaixa nas prácticas do suroeste lucense, aínda que dista do auxe

\footnotetext{
${ }^{14}$ Malia que en cada área predominaban un ou dous modelos, a realidade é que convivían como se pode ver en Guido Alfani, Fathers and godfathers: spiritual kinship in early-modern Italy, Aldershot, Ashgate, 2009, páxs. 42-44.

15 Rey Castelao e Barreiro Mallón, “Apadrinar a un pobre...”, páx. 236. Na Galicia occidental tamén predominou o modelo de parella, pero o individual amosa un calendario máis temperá ao aparecer a mediados do século XVII.

${ }^{16}$ AlFANI, Fathers and godfathers..., páxs. 68-70. Os modelos de apadriñamento múltiple foran duramente criticados polos luteranos por considerar que a Igrexa os permitía co ánimo de enriquecerse ao ter que solicitar dispensas matrimoniais polas citadas restricións.

17 SÁnchez Diego, "Patrones y prácticas asociadas...". Tamén en Cantabria se deron os primeiros casos a inicios do século XVII. Pola contra, en Canarias xa era un modelo arraigado: Jesús Emiliano RoDRíGUEZ Calleja e Alfredo Jesús Viera Ortega, "Padrinazgo y parentesco espiritual en Telde durante el siglo XVI", en XIV Coloquio de historia Canario-Americana, Las Palmas de Gran Canaria, Cabildo Insular de Gran Canaria, 2000, páxs. 948-974.
} 
que acadou nas vilas da zona, onde este modelo máis individual tivo unha mellor acollida: a mediados do século XIX era o modelo do 45\% dos cativos bautizados na vila de Chantada, o 46\% na parroquia principal de Monforte de Lemos e o $59 \%$ en Sarria $^{18}$. Xa que logo, as redes sociais que se buscaba crear co bautismo en Portomarín mantiña un perfil máis próximo ao do mundo rural.

Gráfica 1. Evolución dos modelos de apadriñamento.

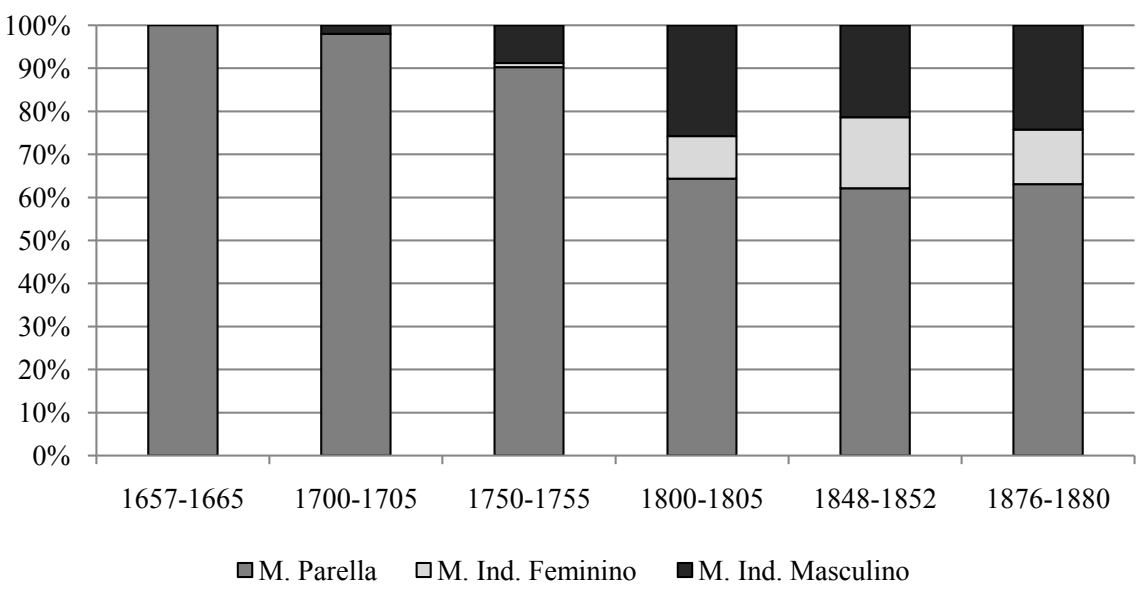

Fonte: Elaboración propia. Mostra de 613 bautismos tomada dos libros bautismais de san Nicolás de Portomarín

Con todo, o recurso a este modelo tampouco se adecuou completamente ao mundo rural. Se, ao comezo do século XIX, o 29,25\% dos bautizados da diocese de Lugo recibían un só padriño, en Portomarín eran o 35,64\%; no tránsito final do século, houbo unha tendencia xeral a empregar de novo o modelo de parella e só o 19,99\% se bautizaba baixo o modelo individual, mais en Portomarín mantívose en niveis semellantes á primeira metade do século. En suma, debemos afirmar que o emprego dos modelos de apadriñamento estivo máis condicionado polas necesidades sociais que a poboación buscaba suplir que polas modas. Amais, nin o paso de transeúntes pola vila supuxo unha pronta adquisición do modelo, nin o asentamento de foráneos nela alterou de xeito significativo os modelos de apadriñamento escollidos.

Con respecto a isto, hai que destacar que só o $20 \%$ dos proxenitores optaron por modelos distintos para a súa proxenie; $24 \%$ si consideramos que se perci-

\footnotetext{
18 Tamara GonzÁlez LópeZ, El padrinazgo bautismal en la diócesis de Lugo (ss. XVI-XIX), Santiago de Compostela, Andavira, 2020, páxs. 81-83
} 
bía como unha estratexia diferenciada modificar o sexo do padriño escollido en solitario. É dicir, un 4\% dos proxenitores optaron polo modelo individual, pero variaron entre homes e mulleres; variación que non tivo como principal factor o sexo do bautizado, xa que foron maioría os que mudaron o sexo do padriño individual sendo o neonato do mesmo sexo que o anterior. Por exemplo, os dous fillos de Manuel López Gandariña e Josefa Vázquez, nados en 1801 e 1803, foron apadriñados por un varón e unha muller respectivamente ${ }^{19}$.

Ao igual ca no resto da diocese lucense, a incorporación da muller ao modelo individual foi posterior ao varón. Ata os anos centrais do século XVIII non se atopa ningunha muller exercendo o amadriñamento en solitario, momento no que representaban auténticas excepcións ${ }^{20}$. A finais do século tiñan un papel menor que os varóns $-9,90 \%$ fronte o $25,74 \%$ - e, aínda que o protagonismo de ambos se asemellou a mediados de século, nas décadas finais os homes recuperaron o rol predominante.

A nobreza local exerceu o papel de difusor das novas modas; aínda que tardiamente e cunha escasa repercusión nos primeiros decenios. Non foi ata o bautismo da primeira filla do matrimonio composto por don Joseph Garro e dona Andrea Taboada y Ulloa, en 1705, que se rexistrou o primeiro caso do modelo de padriño único entre a fidalguía do lugar. Mais o primeiro apadriñamento individual rexistrado para san Nicolás de Portomarín acaeceu en xaneiro de 1688, no bautismo de María, filla de Nicolás de Castro e a súa muller Helena; ata 1696 non se volveu recorrer a este modelo de apadriñamento ${ }^{21}$. A fidalguía local non foi importadora nin creadora das modas no eido dos modelos de apadriñamento; malia iso, non se pode negar o efecto difusor que puideron exercer tras decidir optar por el.

A fidalguía amosa unha leve maior tendencia a exercer de padriños en solitario (13\% fronte a $11 \%)$; mais a pauta mudou entre as mulleres fidalgas, que só actuaron soas no $5 \%$ dos bautizos, fronte ao $8 \%$ do resto das súas coevas. É un síntoma máis do menor rol que as fidalgas de Portomarín desempeñaron no apadriñamento, xa que a súa participación xeral foi inferior á dos fidalgos: $19 \%$ fronte a $10 \%$. O maior control ao que estaban sometidas as mulleres de estratos sociais superiores parece ser o impedimento principal para que participasen nos bautismos con independencia de ser acompañadas polas súas parellas, tanto en solitario como no modelo de parella. Engádese a isto o feito de que fidalgas

\footnotetext{
19 Arquivo Central Parroquial da Diocese de Lugo (en adiante ACPDLu), Libro II (1778-1825), Bautismos de San Nicolás de Portomarín, Arciprestado de Ferreira de Gomelle, fols. 72r. ${ }^{0}$ e 78v. ${ }^{\circ}$.

${ }^{20}$ Rey CAStelao, "Parrains et marraines...". Igualmente aconteceu na zona occidental galega, onde as mulleres amadriñando en solitario non acadaron un espazo destacable ata inicios do século XIX.

${ }^{21}$ ACPDLu, Libro I (1641-1728), Bautismos, Matrimonios y Defunciones de San Nicolás de Portomarín, Arciprestado de Ferreira de Gomelle, fols. 30 e 45.
} 
apenas amadriñaron xunto con persoas que non pertencesen ao seu mesmo grupo social: o 78\% dos varóns cos que se achegaron á pía bautismal eran do seu mesmo grupo social, cifra que nas madriñas que acompañaban aos homes fidalgos se rebaixaba ao $46 \%$. Os lazos de compadreo permitían unha relación más próxima e de maior confianza entre os padriños, razón que levaba a considerar que dita relación podía derivar en tratos ilícitos entre eles ${ }^{22}$. Así pois, evitábanse aqueles apadriñamentos nos que a honra da fidalga puidese ser cuestionada, polo que se preferiu que apadriñasen na compaña dun parente ou, polo menos, doutro fidalgo. O clero, debido ao seu voto de castidade e a respectabilidade social que se lles presupoñía, eran unha parella adecuada para estas madriñas. Pese á súa menor participación, as fidalgas apadriñaron acompañadas dun eclesiástico no mesmo número de ocasións que as campesiñas e artesás. Exemplos disto foron dona Isabel Pardo de Montenegro, veciña da vila, que amadriñou en varias ocasións acompañada do prior frei don Diego de $\mathrm{Yebra}^{23}$; ou o presbítero, residente en san Martín de Caraño, don Antonio de la Vega quen acompañou na pía bautismal tanto a dona Juana Pillado y Bermúdez como á sobriña desta, dona Lucía Garro y Pillado ${ }^{24}$.

Malia estes exemplos, o clero foi o sector máis activo na difusión e adaptación do modelo individual; en teoría, seguindo os preceptos da Igrexa, era o modelo que debía fomentar, posto que creaba menos parentescos espirituais e, por ende, menos restricións matrimoniais. O parco das partidas bautismais do século XVII implica a ausencia de determinada información sobre os actores do bautismo, polo que non é posible aseverar que don Antonio Pardo, o primeiro en exercer de padriño en solitario na vila, estivese relacionado co prior da colexiata de Portomarín, don Juan Pardo. Nos bautismos do século XVIII, si podemos aseverar o rol do clero na normalización deste modelo: tanto no bautismo da filla dos citados fidalgos como nos restantes apadriñamentos individuais dese ano, foi un clérigo o padriño en solitario.

Amais, o clero tiña a potestade de sinalar padriños cando non houbese unha escolla dos pais ou que esta non lles parecese adecuada ${ }^{25}$. En consecuencia, esta era outra vía pola que podían contribuír á difusión dos modelos individuais que, porén, non aplicaron. Os cativos abandonados na vila representaban a mellor oportunidade para que o párroco escollese tanto o modelo de apadriñamento

\footnotetext{
${ }^{22}$ Guido Alfani, "Les réseaux de marrainage en Italie du Nord du XVe au XVIIe siècle: coutumes, évolution, parcours individuels", Histoire, économie et société, 25, 4 (2006), páxs. 36-37.

${ }^{23}$ ACPDLu, Libro I (1641-1728), Bautismos, Matrimonios y Defunciones de San Nicolásde Portomarín, Arciprestado de Ferreira de Gomelle.

${ }^{24}$ ACPDLu, Libro I (1707-1778), Bautismos de San Nicolás de Portomarín, Arciprestado de Ferreira de Gomelle.

${ }^{25}$ IRIGOYEN LÓPEZ, "Ecclesiastical godparenthood in Early...”, páx. 78.
} 
coma os padriños, posto que non había oposición paterna. Con todo, e a pesar de que o fenómeno da exposición non presentou un gran volume na vila, os expósitos bautizados no século XVIII amosan a selección de dous padriños. En xuño de 1754, cando o modelo individual xa acadara un certo espazo, bautizouse unha nena expósita, María Margarita, quen recibiu a Juan Pereira e Margarita López como padriños ${ }^{26}$.

Por conseguinte, pódese apuntar como principal factor da tardía recepción e asimilación do modelo individual na vila de Portomarín ao desinterese que dito modelo tivo entre a elite local. Non foi ata que non se percibiu a súa capacidade de encomiar á figura do padriño, cando estes sectores se interesaron por ese modelo. Amais, o progresivo desenvolvemento da vila cara unhas características urbanas, afectaría tamén ás estruturas demográficas. Fronte ás áreas rurais, nas vilas e cidades había un maior predominio das familias nucleares que, polo tanto, resultaba nun menor número de membros da familia á que poder recorrer como padriños. Isto, unido ao incremento da familia como padriños, que analizaremos máis adiante, contribúe a explicar que o modelo individual só tivera un éxito relativo en Portomarín no século XIX.

\section{O USO SOCIAL DO APADRIÑAMENTO}

Os padriños adquirían un compromiso vitalicio co seu afillado e coa súa familia que, pese a ser de natureza relixiosa, repercutía na vida cotiá de ambos. Era máis que un lazo simbólico co afillado, que supoñía para os padriños unha honra e o reforzo do seu prestixio social dentro da comunidade.

Para que un padriño ou madriña puidese satisfacer por igual as necesidades e demandas de varios afillados debía estar ben situado social e economicamente; razón que levou aos pais a preferir a persoas sen un extenso repertorio de afillados, aínda que tivesen menor influencia social. Optouse por padriños diferentes ou, polo menos, que non tivesen afillados da mesma xeración, para evitar que confluísen varios afillados no mesmo momento do seu ciclo vital. Nos períodos estudados, o $77 \%$ dos padriños e o $88 \%$ das madriñas só aparecen nunha ocasión ante a pía bautismal. En dúas ocasións aparecen o 15\% dos homes e o $11 \%$ das mulleres, aínda que boa parte deles se debía a ser un apadriñamento de xemelgos, quen adoitaban recibir os mesmos padriños. Resta un nada desprezable $8 \%$ de padriños e $7 \%$ de madriñas que exerceron como tal en máis de dúas ocasións, ata o punto de haber casos que superan a ducia como Mariana de Novoa Feixoo, quen amadriñou máis de vinte cativos entre 1657 e 1665.

\footnotetext{
${ }^{26}$ ACPDLu, Libro I de Bautismos de San Nicolás de Portomarín, 1707-1778, fol. 122r. ${ }^{\circ}$.
} 
A reiteración de padriños podía partir dos mesmos proxenitores ao seleccionar ás mesmas persoas para todos ou varios fillos. A reiteración ou diferenciación dos padriños dos fillos determinaba o uso social que a familia daba ao apadriñamento, xa que a través deles podíase buscar afianzar unha relación ou, polo contrario, podíase pretender estabelecer o maior número delas posibles. Na vila de Portomarín predominou esta última, xa que a elección do $75,2 \%$ dos proxenitores recaeu en persoas distintas; namentres, só o 9,4\% dos proxenitores intensificaron a relación a través de todos os fillos. Exemplo disto foi a decisión de José Vázquez e María Juana Varela quen, na segunda metade do século XIX, designaron para apadriñar aos seus dous fillos ao mesmo home, Manuel García, residente na vila e co que non os unían lazos familiares ${ }^{27}$. Resta un $15,4 \%$ dos proxenitores que optaron por un termo medio no que reiteran a elección dunha persoa e, simultaneamente, alternaron outras persoas como padriños. Por exemplo, Antonio e Francisca de San Miguel, a inicios do século XVIII, escolleron á mesma madriña para as súas tres fillas, mais estas tiveron cadanseu padriño. O obxectivo destes pais era perpetuar a relación con esta muller que, ademais, era veciña do lugar de orixe da nai, ao tempo que trataron de prover ás fillas de diferentes redes sociais das que beneficiarse.

A intensificación dos lazos a través do apadriñamento non foi o habitual na diocese. Os primeiros casos déronse na primeira metade do século XVIII; momento no que era unha estratexia empregada polo $9 \%$ dos proxenitores do principal núcleo urbano da diocese, a cidade de Lugo. Na vila de Portomarín, no mesmo período, acadaba o $7 \%$ e, probablemente, era unha práctica procedente das urbes galegas, como Santiago de Compostela ou, incluso, de fóra do territorio galego ${ }^{28}$. Non obstante, tamén se pode considerar que se tratou dunha derivación extrema da posibilidade intermedia citada, posto que, ao contrario que a reiteración total dos padriños, hai exemplos da escolla repetida de varios padriños nos rexistros máis antigos. Tratábase dun número baixo de pais que buscaban reforzar o lazo con determinadas persoas, xa fose nunha estratexia pretendida, xa fose por ausencia doutras opcións ${ }^{29}$.

Agora ben, sería conveniente realizar esta análise baixo o parámetro de familias ou casas, xa que as relacións sociais afectaban a estas no seu conxunto e non só aos seus protagonistas de xeito individual. Así, unha elección a priori

\footnotetext{
${ }^{27}$ ACPDLu, Libro IV (1852-1880), Bautismos de San Nicolás de Portomarín, Arciprestado de Ferreira de Gomelle, fols. $172 \mathrm{r}^{\circ}$ e $185 \mathrm{v} .^{\circ}$.

${ }^{28}$ Sylvie Nathalie HANICOT BourdiER, "Ensayo sobre la religiosidad de una comunidad vasca en los siglos XVIII y XIX”, Procesos históricos: revista de historia, arte y ciencias sociales, 10 (2006), páx. 6. Na zona vasca predominaba a intensificación dos lazos.

${ }^{29}$ Rey Castelao, "Parrains et marraines...", páxs. 74-81. Pódese comprobar como para a proxenie de varias familias compostelás, habidas na primeira metade do século XVIII, desenvolvéronse estratexias mixtas ao repetir padriños para varios fillos, pero mantendo tamén unha diversidade nas redes.
} 
diversa podía agochar unha estratexia de afianzamento das relacións cunha soa familia, ao seleccionar a distintos membros desta; estratexia que non só permitía fortalecer o vínculo entre ambas familias, senón que tamén favorecía a individualización dos lazos sociais de cada fillo. Por exemplo, Francisca Méndez e o seu marido, Manuel de Castro, evidencian o intento de consolidar a relación coa familia paterna, tamén residente na vila, pois designan a dúas tías e ao avó dos bautizados como padriños.

En suma, a elección de padriños respondía a unha estratexia decidida polos proxenitores que podía variar entre a proxenie dependendo das circunstancias que fose atravesando a familia no seu ciclo vital. Amais, non se debe descartar que pais que pretendesen empregar unha estratexia de intensificación dos vínculos tiveran que mudar de idea polo pasamento ou emigración dos padriños.

\section{A POSICIÓN SOCIAL DOS PADRIÑOS}

A posición social dos padriños era importante en tanto amosaba unha busca de protección por parte dos proxenitores cando preferían a grupos sociais de maior rango có propio ou, pola contra, o intento de favorecer a integración no tecido social da vila ao designar padriños dentro do mesmo grupo.

A meirande parte dos padriños escollidos non formaba parte da fidalguía nin nobreza local, pois só representaron o $22 \%$ do total de padriños. Mais trátase dunha cifra importante, en tanto era un sector que representaba o 5,3\% das familias da vila e o só o $4,6 \%$ ao cinguirse á parroquia de san Nicolás. Sen dúbi$\mathrm{da}$, este continxente tivo un papel destacado no apadriñamento, que tamén se observa nas medias de afillados en cotas superiores aos coetáneos non fidalgos; especialmente, as mulleres fidalgas: 1,68 afillados de media fronte a 1,35 das non fidalgas. A participación máis asidua dos fidalgos tamén se percibe no tempo que tardaban en volver ser requiridos como padriños: aínda que a diferenza era escasa, os fidalgos solicitados en máis dunha ocasión apadriñaron cada once meses e as fidalgas cada trece, fronte aos quince e catorce meses dos homes e mulleres, respectivamente, que non pertencían ao estamento privilexiado e reiteraban o seu rol apadriñador. A maior presenza da fidalguía como padriños de bautismo explícase, en parte, polo escaparate social que supoñía ${ }^{30}$. Ao ser unha cerimonia que acontecía no espazo do templo parroquial e que, polo menos durante os séculos XVI-XVIII, tendía a celebrarse ante a comunidade parroquial,

\footnotetext{
30 Antonio Presedo Garazo, "La preeminencia social de la nobleza gallega en el espacio sagrado durante los siglos XVI y XVII", Diversarum rerum: revista de los Archivos Catedralicio y Diocesano de Ourense, 9 (2014), páxs. 410-411. O espazo de convivencia que representaba a igrexa parroquial permitía á fidalguía desenvolver diversas estratexias para aproveitar o reflexo da posición social que se trasladaba a ela.
} 
constituía unha ocasión clave para amosar e fortalecer a súa condición dentro do tecido social.

O recurso á fidalguía oscilou ao longo de toda a Idade Moderna: percíbese un constante aumento dende mediados do século XVII, cando eran o $9 \%$ dos padriños, ata inicios do século XIX, período no que ascenderan ata o $18 \%$. Ao longo do século XIX, a fidalguía foi perdendo espazo social no apadriñamento, paralelamente aos cambios derivados das Cortes de Cádiz, do liberalismo e a redención de foros que minaron o seu poder social e económico.

Mais hai que valorar estas porcentaxes atendendo á condición social dos proxenitores que os seleccionaron. Boa parte dos nobres e fidalgos que foron padriños frecuentes fórono por ser escollidos por pais do mesmo estamento social; como don Antonio de la Vega, presbítero, padriño dos dous fillos do avogado don Manuel Garro y Ulloa e dona Josefa de Yebra Bermúdez y Santiso ${ }^{31}$. Nese senso, contribuíu que a fidalguía tivese, de media, un número maior de fillos có resto das familias ${ }^{32}$. Os proxenitores que non pertencían á fidalguía recorreron en menor medida a eles (12\%), pois preferían optar polo endopadriñado social; é dicir, por veciños que representasen unha integración social efectiva e unha axuda nas labores da vida cotiá3 ${ }^{3}$. De feito, é maior o volume de proxenitores da fidalguía que se decantaron por padriños de condición social inferior (32\%) que á inversa ${ }^{34}$.

A escasa tendencia a buscar a protección da nobreza local explícase por dous motivos. Por unha banda, o número de fidalgos residentes na vila non superaba o $6 \%$, polo que constituían unha elite reducida numericamente que os levaría a distanciarse do resto da poboación para marcar as diferenzas do seu grupo social $^{35}$. Como xa se apuntou, a fidalguía tendeu ao endopadriñado social, agás no século XIX, polo que se viron obrigados a recorrer a fidalgos doutras freguesías para apadriñar polo seu baixo número. Por exemplo, don Manuel María Páramo, señor da casa de Villeiriz (concello do Páramo) apadriñou a unha filla de don

\footnotetext{
31 ACPDLu, Libro I (1707-1778), Bautismos de San Nicolás de Portomarín, Arciprestado de Ferreira de Gomelle, fols. 111 r. $^{\circ}$ e $116 v^{\circ}$.

${ }^{32}$ Isidro Dubert García, Historia de la familia en Galicia durante la época moderna, 1550-1830: (estructura, modelos hereditarios y conflictividad), Sada, Ediciós do Castro, 1992, páx. 119. A mediados do século XVIII, a fidalguía presenta unha media de 2, 45 fillos, fronte a 1, 88 dos labradores.

33 Rey CAStelao, "De la casa a la pila...”, páx. 207. Obsérvase a mesma tendencia a apadriñar dentro do mesmo grupo social noutras áreas de Galicia, como Santiago de Compostela.

${ }^{34}$ Michel Bertrand, "Familles, fidèles et réseaux: les relations sociales dans une société d'Ancien Régime”, en José Luis Castellano e Jean-Pierre Dedieu (eds.), Réseaux, familles et pouvoirs dans le monde ibérique à la fin de l'Ancien Régime, Paris, CNRS Editions, 1998, páxs. 184-185. Os estudos para outras zonas peninsulares sitúanse no polo contrario, ao observar unha maior preferencia por buscar a integración vertical e establecer un apadriñamento de corte clientelar.

${ }^{35}$ Contabilizando ambas parroquias, os fidalgos encabezaban o 5,3\% das familias e constituían o 5,5\% dos habitantes.
} 
José Sánchez Arias e dona Francisca Romero ${ }^{36}$. A consecuencia do afastamento entre a fidalguía e o resto da poboación, esta última optou por outros sectores con influencia na vila como, por exemplo, Domingo Antonio Fernández Saavedra, quen consta no Catastro da Ensenada como tenente de xuíz, amais de labrador, e que se configura como un dos principais padriños a mediados do século XVIII, xunto con Juan Pereira, carcereiro da vila ${ }^{37}$. Representaban veciños de igual condición social e de recoñecida autoridade na vila.

O outro factor é a heteroxeneidade interna da fidalguía. Ao carón de familias cun destacado poder económico e inmersas en redes sociais potentes, había outras familias que o único que corroboraba a súa calidade fidalga era a exención de levas ${ }^{38}$. Estas familias compartían máis costumes e tarefas coa poboación xeral que con outras familias fidalgas, polo que a efectos de apadriñamento tiñan a mesma consideración que o resto de veciños e, polo tanto, non provían da protección e outros beneficios sociais que se esperaban do apadriñamento ascendente.

Malia a súa influencia social, o clero tampouco foi un sector recorrente como padriños, pois só exerceron como tal no $8 \%$ dos bautismos. Nesa porcentaxe non se atopa só o clero vinculado coa colexiata de Portomarín, senón que tamén houbo unha proporción importante de párrocos doutras freguesías próximas como, por exemplo, o de san Mamede de Belaz ou san Lourenzo de Fiz de Rozas; tamén eclesiásticos doutras parroquias máis afastadas, como o de santa María de Sirvián (Guntín). Porén, foron os diferentes priores de Portomarín os principais axentes apadriñadores do clero, posto que o prestixio e a rede social que aportaban era superior.

O proceso de perda de importancia como padriños que sufriu este continxente é similar ao da fidalguía local. A mediados do século XVII, o 13\% dos bautizados eran apadriñados polo prior ou outro membro da colexiata; mais esta cifra descendeu ata chegar aos seus mínimos históricos a mediados do século XIX, cando só un eclesiástico foi escollido como padriño -aínda que o foi para tres cativos-. Os obxectivos depositados no apadriñamento foran mudando cara ao ámbito familiar, en detrimento dos axentes sociais predominantes no espazo público, coma a Igrexa.

En xeral, percíbese unha leve interrelación social dos distintos sectores da vila portomariñense. Ao contrario que noutras zonas peninsulares, non semella

\footnotetext{
${ }^{36}$ ACPDLu, Libro III (1825-1852), Bautismos de San Nicolás de Portomarín, Arciprestado de Ferreira de Gomelle, fols. 136r. ${ }^{\circ}$.

37 Archivo General de Simancas, Catastro de Ensenada, Respuestas Generales, Libro 183, fols. 749r. ${ }^{\circ}$ 750v. ${ }^{\circ}$.

38 Pegerto SAAvedra FernÁNDEz, "La vida en los pazos gallegos: entre la civilidad y la rudeza", Chronica nova: Revista de historia moderna de la Universidad de Granada, 35 (2009), páx. 167.
} 
haber unha verticalización ascendente das relacións sociais, senón que, máis ben, habería que apuntar a un intento xeral da fidalguía por integrarse cos seus veciños. Certas familias con maior poder social e económico mantiveron unha actitude de reforzamento de grupo e diferenciación social; mais, outras familias que no cotiá non se diferenciaban do resto de seus veciños, optaron por esa integración.

\section{A VECIÑANZA DOS PADRIÑOS}

En xeral, a poboación escolleu padriños residentes na mesma parroquia có afillado, nunha proporción que rozou o $60 \%$. Este alto nivel de veciñanza é preciso valoralo en relación ás obrigas que os padriños contraían cos seus afillados, entre as que a Igrexa destacaba a protección espiritual e ensinar a doutrina cristiá. Estas requirían un maior contacto e relación cotiáns, polo que a residencia na mesma parroquia ou, polo menos, nas parroquias circundantes era precisa. Amais, a creación destes vínculos tamén tiña por obxectivo responder ás necesidades dos proxenitores, para quen esa proximidade se podía traducir na cooperación nos quefaceres agrícolas, sobre todo naqueles momentos de maior traballo que precisaban a unión colectiva.

A relación padriño-afillado ou de compadres permitía un aproveitamento amable dos recursos do outro; amais, obrigaba a asistir e axudarse mutuamente, tanto en aspectos relativos á vida cotiá como en sucesos máis excepcionais como conflitos xudiciais ${ }^{39}$. En principio, isto significaba non poder actuar en contra do afillado ou de seus pais; unha alianza que era fundamental no rural galego, onde a conflitividade entre veciños era frecuente, aínda que non toda ela derivase en preitos ante a xustiza ${ }^{40}$. As autoridades pertinentes eran conscientes do que podía implicar esta relación, polo que as testemuñas nun proceso xudicial debían declarar a existencia de parentesco espiritual cos implicados no conflito.

De tódolos xeitos, tampouco debemos desprezar a utilidade que podía ter seleccionar padriños fóra do marco parroquial; especialmente, para os proxenitores que podían combinar varias estratexias de apadriñamento. Atendendo a que a mediados do século XVIII a media de fillos era de 4,3, existía prole suficiente para tentar diversificar as estratexias tanto en número de padriños como nas súas características ${ }^{41}$. Por exemplo, un padriño doutra parroquia podía servir

\footnotetext{
39 Alfani, Fathers and godfathers..., páx. 59.

40 Ofelia Rey Castelao, "La lucha por el agua en el país de la lluvia: Galicia, siglos XVI-XIX", Vínculos de Historia, 1 (2012), páxs. 50-51. A meirande parte destes conflitos resolveuse paraxudicialmente.

${ }^{41}$ Hortensio SoBrado CORREA, "Transformaciones agrarias, estrategias hereditarias y crecimiento demográfica en las tierras lucenses, 1750-1860”, Obradoiro de Historia Moderna, 5 (1996), páx. 11.
} 
de enlace para convir un matrimonio. Ou, quizais máis útil para toda a familia, representaba un fogar no que poder facer noite; aspecto importante naqueles lugares onde había mercados ou feiras ${ }^{42}$. Amais, como veremos, unha parte destes padriños que non residían na mesma parroquia que o seu afillado eran parentes carnais, polo que optar por eles respondía a outro tipo de estratexia: o reforzamento dos lazos familiares.

En total, descoñecemos a residencia do $13 \%$ dos padriños, polo que resta un $27 \%$ deles que si vivían noutras parroquias. Neles, predominan os procedentes de parroquias circundantes coma santa María de Cortapezas, cuxos veciños aparecen frecuentemente como padriños na vila. En troques, a proporción de padriños que residían a unha distancia considerable do seu afillado foi ínfima; aínda que houbo casos como os procedentes de Santiago das Somozas (A Coruña) ou da propia cidade herculina. Estes apadriñamentos nos que a distancia acada cotas considerables tratábanse, máis ben, de procurar un apoio ou persoa de referencia fóra dos marcos de sociabilidade cotiás, en lugar de representar unha segunda paternidade para o afillado.

A diversidade de orixe dos proxenitores tivo incidencia no nivel de veciñanza que se acadou nos padriños. Cando ámbolos pais eran nacidos na parroquia de san Nicolás de Portomarín, optaron por un $78 \%$ de padriños residentes na mesma, fronte a un $71 \%$ de madriñas residentes. Non se pode valorar a existencia dunha maior preferencia de homes veciños neste caso, posto que o número de madriñas cuxa residencia descoñecemos triplica ao de varóns (11,8\% e 4,3\%, respectivamente).

O nivel de veciñanza do padriño tivo unha menor dependencia da orixe xeográfica dos proxenitores có das madriñas, posto que neles oscilou entre $65-78 \%$, rango que nelas abranguía o $19-78 \%$. O rol outorgado a cada sexo dentro do apadriñamento - a muller encárgase da protección espiritual, namentres que o varón a material- explica a importancia que, nun marco como a vila de Portomarín, tiña a corresidencia co padriño ${ }^{43}$. É dicir, a tenor deses datos, poderíase dicir que se prefería que a integración social partise do home, dada a súa maior presenza e acceso a máis eidos sociais cá muller.

O maior nivel de padriños alóctonos da vila de Portomarín acadábase cando só o pai era natural do lugar. Polo contrario, entre as madriñas a oscilación segundo a orixe dos proxenitores presenta un maior contraste. Pódese apreciar

\footnotetext{
42 Pegerto SaAvedra Fernández, "La consolidación de las ferias como fiestas profanas en la Galicia de los siglos XVIII y XIX”, Sémata: Ciencias sociais e humanidades, 6 (1994), páxs. 285-286. A abundancia de gando e o comercio téxtil favoreceron a aparición de feiras e mercados na provincia de Lugo á que acudían veciños doutras zonas.

${ }^{43}$ Françoise Zonabend, "La parenté baptismale à Minot (Côte-d'Or)", Annales. Économies, Sociétés, Civilisations, 33, 3 (1978), páx. 662.
} 
como as madriñas foráneas eran máis habituais cando a nai tamén o era: o $61 \%$ das madriñas fronte ao $25 \%$ cando a nai era nativa da vila. En troques, esta diferenza non se observa entre os padriños escollidos por un pai foráneo e unha nai nativa, perfil de parella que presenta o mesmo esquema de elección de padriños que cando ambos son nativos.

Gráfica 2. Veciñanza de padriños e proxenitores.

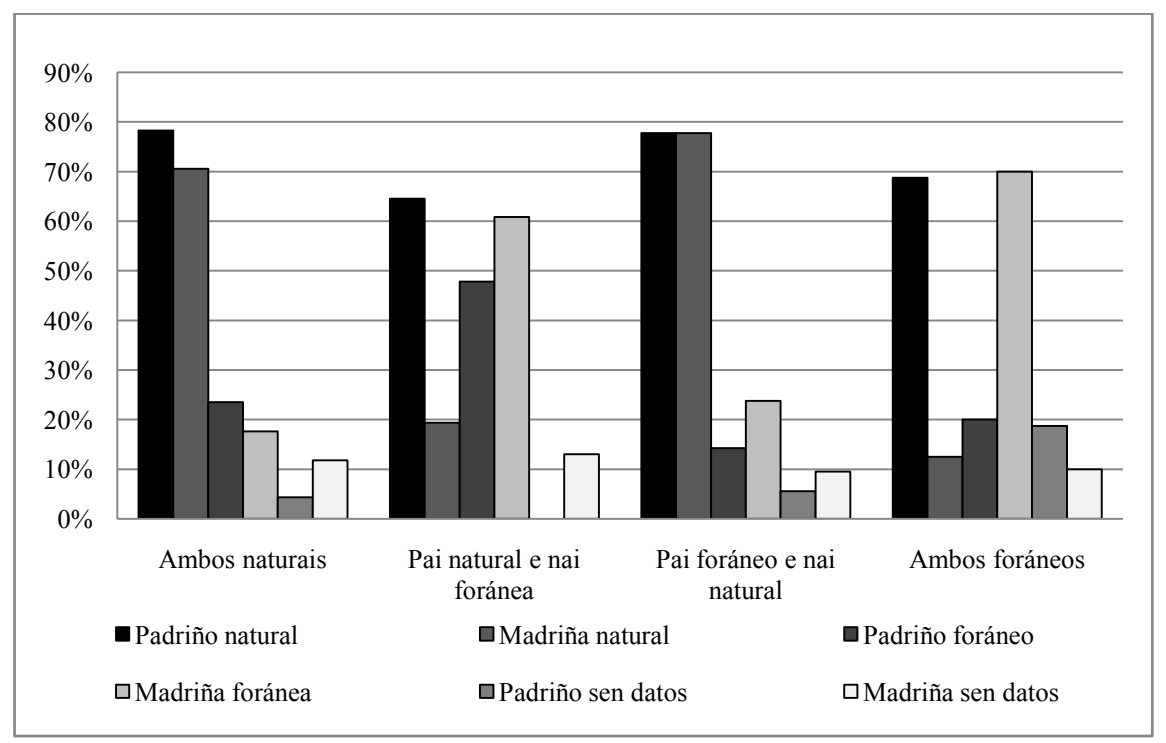

Fonte: Elaboración propia. Mostra de 613 bautismos tomada dos libros bautismais de san Nicolás de Portomarín.

Aínda que a tendencia foi seleccionar padriños da mesma naturalidade que a nai, houbo excepcións. Nalgúns casos optaron por padriños de distintos lugares como, por exemplo, Manuel Pérez e María Manuela González Rivera, que para o seu primeiro fillo o padriño foi un veciño da parroquia de san Vicente de Paradela, de onde era orixinaria María Manuela, e para o segundo por un pai e máis a súa filla, veciños de Portomarín ${ }^{44}$. A estratexia para os fillos de Juan Manuel Arias e Antonia Penela foi á inversa, designando para o primeiro fillo a un veciño de Portomarín e, para o segundo, a unha parella residentes no lugar de orixe da nai ${ }^{45}$.

\footnotetext{
44 ACPDLu, Libro IV (1852-1880), Bautismos de San Nicolás de Portomarín, Arciprestado de Ferreira de Gomelle, fols. 174r. ${ }^{\circ}$ e 191r. ${ }^{\circ}$.

45 ACPDLu, Libro IV (1852-1880), Bautismos de San Nicolás de Portomarín, Arciprestado de Ferreira de Gomelle, fols. 170r. ${ }^{\circ}$ e 190r. ${ }^{\circ}$.
} 
A estratexia seguida á hora de seleccionar padriños podía variar en función do sexo do bautizado, pero era a orde de nacemento a que más afectaba na escolla dos padriños ${ }^{46}$. Para os primeiros fillos, tendíase a preferir a persoas do lugar no que residían, de tal xeito que, a través do apadriñamento, se lles procurasen unha abano de relacións das que poder valerse, tanto no presente coma no futuro, e que lles facilitasen a integración na vida social da vila. Entre os proxenitores que se decantaron por padriños de distinta veciñanza atópanse situacións moi específicas. Por exemplo, pais que están de caseiros polo que, conscientes da temporalidade do seu arraigo no lugar, optan para os seus tres fillos por padriños da súa parroquia de orixe e, concretamente, para a primeira en nacer polos avós maternos ${ }^{47}$. Queda patente que as estratexias á hora de escoller padriños eran matinadas e respondían ás circunstancias nas que se atopaban os proxenitores.

\section{O PARENTESCO DOS PADRIÑOS}

A existencia de parentesco carnal entre padriños e afillados é unha peza clave na análise do apadriñamento e o seu impacto nas dinámicas familiares. Os proxenitores podían buscar o reforzamento do grupo familiar interxeneracional ou, na perspectiva oposta, estender os lazos sociais fóra dese grupo. Incluso, podían empregarse ambas estratexias ao seleccionar dous padriños e que só un fose parente.

Empregando os datos sobre os lazos familiares entre padriños e afillados de toda a Idade Moderna, só se pode confirmar a existencia de parentesco no $9 \%$ dos padriños e $11 \%$ das madriñas ${ }^{48}$. A fraxilidade dos sistemas de transmisión de apelidos e a mutabilidade dos mesmos nos séculos XV-XVI, provoca que a probabilidade de ocultación da relación familiar sexa elevada. Só podemos empregar a homonimia como factor de posible parentesco, pero o parco dos datos proporcionados polos párrocos destes séculos non contribúe a esclarecer que padriños eran parentes dos bautizados; referencias que se apuntan con maior frecuencia a inicios do século XIX, mais non sistematicamente.

Para o século XIX, a proporción de padriños que eran parentes dos seus afillados rozaba o $20 \%$, mentres as madriñas superaban o $26 \%$; cifras superiores ás

\footnotetext{
${ }^{46}$ Alfani, "Les réseaux de marrainage...", páx. 27. Os estudos sobre Italia amosan que, cando estaban permitidos os modelos de apadriñamento múltiples, os primoxénitos tiñan un maior número de padriños e de maior rango social ca seus irmáns.

47 ACPDLu, Libro IV (1852-1880), Bautismos de San Nicolás de Portomarín, Arciprestado de Ferreira de Gomelle, fols. 176v. ${ }^{\circ}, 183 \mathrm{r}^{\circ}$ e $193 \mathrm{r} .^{\circ}$.

48 Ansón CALVO, "Sociología del bautismo...", páx. 88. En Zaragoza, no século XVII, a proporción de padriños que eran familia do bautizado non superaba o $9 \%$.
} 
dadas para todo o período ${ }^{49}$. Se ben, como xa se dixo, aumentan as referencias ao parentesco, certifícase que se produciu unha crecente participación da familia como padriños: triplícase ao longo de dito século ${ }^{50}$. Pese ao incremento, estas cifras son inferiores ás recollidas para outras zonas nas que o continxente de foráneos era exiguo ou inexistente ${ }^{51}$. Ao tratarse dunha pequena vila, a poboación inmigrante non suporía un sector moi numeroso, pero si o suficiente para alterar levemente as tendencias e prácticas do apadriñamento e, especialmente, na elección do número de familiares ${ }^{52}$. As pautas de selección dos padriños en parellas de pais conformadas por foráneos e naturais eran semellantes a aquelas nas que ambos eran locais, pero nas primeiras entraba en xogo o factor distancia, polo que o seu recurso á familia era inferior. Amais, estes tiñan outras prioridades que tentar cubrir como a creación de redes sociais dentro da vila, polo que optarían por veciños en lugar dos familiares que se puidesen achegar puntualmente á vila. ${ }^{53}$. De feito, pódese entrever a necesidade de establecer lazos fóra do marco familiar que, no século XIX, un reducido $1,8 \%$ dos padriños fosen irmáns do bautizado que, en determinadas situacións, serían a única familia na vila ${ }^{54}$. Os proxenitores que designaron a un dos seus fillos como padriño doutro fillo en Portomarín foron escasos, pero todos eles coinciden en que un dos pais era natural da vila; é dicir, os proxenitores que emigraran en parella optaron sempre por outras persoas, aínda que fosen alleas á familia, nun intento de formar unha rede social o máis ampla e densa posible: ningunha das parellas constituídas por foráneos, a mediados do século XIX, recorreron a un familiar como padriño.

\footnotetext{
49 Porén, son cifras inferiores ás doutras áreas estudadas, como Albacete por Cosme Jesús GómEz CARRASCO e Francisco GARCía GonZÁLEZ, "Parentesco ficticio y red social en la España meridional (Albacete, 1750-1808)", Popolazione e Storia, 1 (2008), páx. 42, onde na segunda metade do século XVIII, o $43 \%$ dos padriños eran familiares.

50 Agnès FINE, "L'héritage du nom de baptême", Annales. Économies, Sociétés, Civilisations, 42, 4(1987), páx. 872. Nas familias burguesas xa se constata o incremento da elección de parentes como padriños dende o século XVI.

${ }^{51}$ GonZÁlez LóPez, “Apadriñamento no Arciprestado...”, páx. 101. Por exemplo, no arciprestado de Bolaño, próximo á capital lucense, as madriñas que tiñan lazos familiares cos seus afillados xa ascendía ao $31,5 \%$ a mediados do século XIX.

${ }^{2}$ SÁnchez Diego, "Padrinazgo bautismal e inserción...", páx. 1675. Cando un dos proxenitores era foráneo, optábase por padriños da mesma localidade, salvo se eran familiares. Unicamente cando existía unha comunidade de certa proporción como os vascos en determinadas zonas de Cantabria erixían o factor "paisanaxe" como criterio de elección.

${ }^{53}$ Agnès Fine, "Transmission des prénoms et parenté en Pays de Sault, 1740-1940", en Jacques Dupâquier, Alain Bideau e Marie-Elizabeth Ducreux (eds.), Le Prénom: mode et histoire: entretiens de Malher 1980, Paris, École de Hautes Études, 1984, páx. 110. Salvo grandes distancias, buscábase que a familia participase no apadriñamento.

${ }^{54}$ Tamara GONZÁLEZ LÓPEZ, Madriñas de brazo, padriños de pía: apadriñamento e bautismo no suroeste de Lugo (séculos XVI-XIX), Lugo, Asociación de Amigos do Mosteiro de Ferreira de Pallares, 2019, páxs. 83-84. Os irmáns do bautizado participaron activamente como padriños cando a familia emigrara.
} 
Ademais dos cambios internos nas dinámicas familiares, é preciso apuntar tamén a outros factores que contribuíron ao aumento da súa participación como padriños. Ao longo da Idade Moderna reducíronse considerablemente os días que se deixaba transcorrer entre o nacemento e o bautismo, ata o punto de que, a finais do século XIX, o 25\% dos nenos de Portomarín se bautizaban o propio día de nacemento e o $54 \%$ ao día seguinte. A imposibilidade de saber a data exacta do parto, amais do reducido tempo de espera, obrigaba a ter que designar a persoas das que se sabía a súa dispoñibilidade para tal mester, polo que tíos e avós do bautizado foron os principais elixidos ${ }^{55}$.

Independentemente da época analizada, a proporción de familiares de cada rama mantense en niveis semellantes: mentres a rama paterna oscila entre o $33,7 \%$ e o $38,9 \%$, a materna supón sempre máis da metade. Xunto a eles, os irmáns representan entre o $7,6 \%$ e o $13 \%$, agás na primeira etapa onde tiñan unha presenza nula. Isto débese a que os irmáns representan o derradeiro elo da familia ao que recorrer polo que, ata que está avanzada a tendencia a optar por parentes, representan a última elección desexada ${ }^{56}$.

Queda patente, polo tanto, que á hora de escoller padriños valorábase en primeiro lugar a conexión coa familia materna. Recordemos que a provincia de Lugo tivo durante toda a Idade Moderna un marcado carácter patrilocal nos matrimonios, polo que o apadriñamento podería considerarse unha vía de equilibrio entre ámbalas ramas; así como un xeito de manter activa a relación coa familia materna, sobre todo, cando a nova residencia da muller ao contraer matrimonio superaba os límites parroquiais onde nacera. Así, a familia paterna representaría a familia de convivencia e a materna, a espiritual.

Convén subliñar que no maior peso da familia materna contribúe a tendencia a que apadriñasen matrimonios xuntos. Dos parentes que apadriñan en matrimonio, o $40 \%$ son tíos maternos, outro $40 \%$ os avós maternos, namentres os $20 \%$ restante eran tíos ou avós pola rama paterna. Nunha área de predominio dun sistema hereditario que favorecía que o varón primoxénito perpetuase o fogar familiar, a probabilidade de que unha muller tivese irmáns era superior á do home: a nai, casada para outra casa, tería polo menos un irmán casado na que fora a súa casa de orixe, mentres que os tíos paternos quizais permanecesen

\footnotetext{
55 Rey CAstelao, "De la casa a la pila...”, páx. 205. Apunta a dito factor como causa do incremento de padriños da mesma parroquia, factor que tamén explicaría o maior recurso á familia.

${ }^{56}$ Didier LetT, “Les frères et les soeurs, 'parentes pauvres' de la parenté”, Medievales: Langue, textes, histoire, 54 (2008), páx. 5. A relación entre os proxenitores e os padriños era concibida como unha relación case fraternal, polo que se trataba de evitar o apadriñamento por parte de irmáns, posto que se tería, ao mesmo tempo, unha relación paternal e fraternal. Ademais, se o apadriñamento situaba ao padriño nunha posición superior ao pai, como afirma PITT-RIVERS, "L'elecció del padrí...”, páx. 91, o apadriñamento por parte de irmáns poñería a estes nun plano social superior respecto ao proxenitor.
} 
célibes no fogar. Amais, a menor idade do matrimonio da muller implicaba unha maior probabilidade de que os avós maternos fosen máis novos cós paternos e, por conseguinte, máis plausible que vivisen ambos ao nacer os netos ${ }^{57}$.

Gráfico 3. Evolución da proporción das ramas familiares no apadriñamento

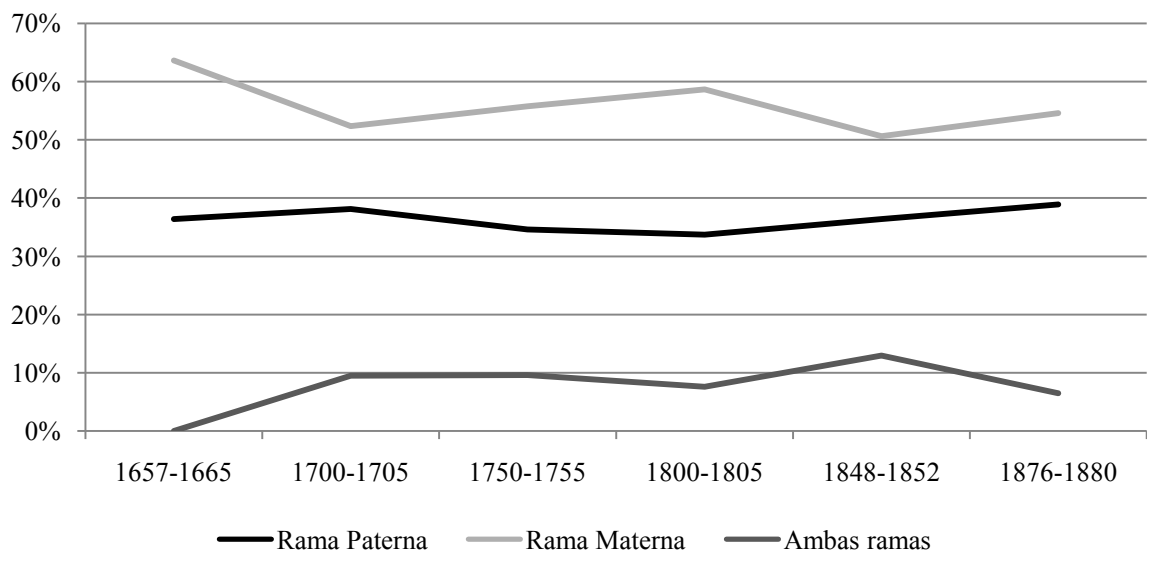

Fonte: Elaboración propia. Selección dos parentes que apadriñan nunha mostra total de 613 bautismos tomada dos libros bautismais de san Nicolás de Portomarín.

Tamén é preciso apuntar a outro factor que contribuíu a que a rama materna apadriñase en maior medida: a ilexitimidade. Aqueles fillos naturais que eran anotados como fillos de pai incógnito non proporcionan información sobre a rama paterna, polo que os padriños, aínda que fosen efectivamente parentes polo pai, non se constan como tal. A ilexitimidade na vila de Portomarín chegou aos seus máximos a mediados do século XIX, cando o $15,5 \%$ dos nacidos eran fillos naturais; momento no que, amais, a Igrexa instaba aos párrocos a non anotar o nome do suposto pai catar mediase a xustiza ${ }^{58}$. Nesta situación, tanto os avós como os tíos maternos foron os padriños aos que máis se recorreu, amais de veciños. Con todo, hai bautismos de difícil clasificación como a viúva cuxo fillo natural foi apadriñado polo irmán do seu defunto marido.

En suma, podemos afirmar que a familia se configurou como unha fonte de padriños ao longo da Idade Moderna como consecuencia do progresivo peche

\footnotetext{
${ }^{57}$ Hortensio Sobrado Correa, Las tierras de Lugo en la Edad Moderna: economía campesina, familia y herencia, 1550-1860, A Coruña, Fundación Pedro Barrié de la Maza, 2001, páx. 436.

${ }_{58}$ Isidro Dubert García, "Église, Monarchie, mariage et contrôle social dans la Galice rurale, XVIIIeXIXe siècles”, Annales de démographie historique, 2 (2009), páxs. 114-115.
} 
da familia respecto á sociedade ${ }^{59}$. Así, o bautismo pasou a ser un lazo máis individual e familiar, en lugar de constituír un aglutinante social.

\section{CONCLUSIÓN}

$\mathrm{O}$ vínculo entre padriños, proxenitores e afillados era máis có simple lazo afectivo, pois tiña implicacións no decorrer cotián. A selección de padriños realizouse no entorno máis próximo da familia, tanto en termos residenciais como de parentesco. Os padriños configuráronse como unha peza clave para a integración na comunidade e nas súas redes, bardante que se trataba dun vínculo de orixe relixiosa.

Malia tratarse dunha vila, en Portomarín reproducíanse numerosas trazas na escolla de padriños dos espazos rurais, coma a menor preferencia que se tivo polo modelo individual ou a maior participación das familias maternas. Porén, tampouco reproducía con exactitude as tendencias do rural, senón que a súa condición de centro comarcal supoñían unhas características específicas que influían nas necesidades e nas estratexias sociais da poboación. En xeral, os proxenitores trataron de diversificar os seus lazos sociais polo que cada fillo tivo cadanseus padriños e antepuxeron o factor da veciñanza a outros coma a pertenza á fidalguía. No século XIX, o parentesco carnal comezou a xogar un papel fundamental á hora de seleccionar padriños, incluso entre as familias recentemente chegadas á vila.

As pautas de elección de padriños en Portomarín seguiron a mesma dirección que no resto de Galicia e Europa: unha fase na que se priorizaban aos veciños como un xeito de reforzar a comunidade, seguida doutra fase na que a familia emerxeu como continxente principal de padriños, ao calor da progresiva separación da familia da esfera pública que comezou no século XVIII entre a burguesía francesa. Pola contra, non se observa esa fase inicial de apadriñamentos da elite procurando o seu amparo e protección; aínda que o tardío inicio dos rexistros bautismais poda ser a principal explicación, posto que se trataba dun comportamento observado máis claramente nos séculos XVI e XVII.

Cómpre, para poder tomar conciencia e coñecer as repercusións deste vínculo máis alá do plano afectivo, realizar investigacións máis exhaustivas que aborden esta relación no plano económico e cultural, malia a omisión sistemática na

\footnotetext{
${ }^{59}$ Philippe Ariès, El Niño y la vida familiar en el antiguo régimen, Madrid, Taurus, 1987, páx. 528. Outros autores, como Guido AlfanI, "La Iglesia y el padrinazgo: ¿una institución social rebelde? (Italia, España y Europa desde el siglo V hasta la actualidad)", Revista de Demografia Histórica, 26 (2008), páxs. 87-124, apuntan tamén á perda de importancia do parentesco espiritual.
} 
documentación oficial da relación de padriños, compadres e afillados, que si é posible atopar na documentación epistolar privada.

\section{BIBLIOGRAFÍA}

Alfani, Guido, Fathers and godfathers: spiritual kinship in early-modern Italy, Aldershot, Ashgate, 2009.

Alfani, Guido, "La Iglesia y el padrinazgo: ¿una institución social rebelde? (Italia, España y Europa desde el siglo V hasta la actualidad)", Revista de Demografía Histórica, 26 (2008), páxs. 87-124.

Alfani, Guido, "Les réseaux de marrainage en Italie du Nord du XVe au XVIIe siècle: coutumes, évolution, parcours individuels", Histoire, économie et société, 25, 4 (2006), páxs. $17-44$.

Alfani, Guido; Castagnetti, Philippe e Gourdon, Vincent (eds.), Baptiser: pratique sacramentelle, pratique sociale (XVIe-XXe siècle), Saint-Étienne, Université de Saint-Étienne, 2009.

Alfani, Guido, e Gourdon, Vincent (eds.), Spiritual Kinship in Europe, 1500-1900, London, Palgrave Macmillan, 2012.

Alfani, Guido; Gourdon, Vincent, e Robin, Isabelle (eds.), Le parrainage en Europe et en Amérique. Pratiques de longue durée, XVIe-XXIe siècle, Bruxelles, Peter Lang, 2015.

Ansón Calvo, María del Carmen, "Sociología del bautismo en el siglo XVII", Cuadernos de investigación: Geografía e historia, 3 (1977), páxs. 69-90.

Ariès, Philippe, El Niño y la vida familiar en el antiguo régimen, Madrid, Taurus, 1987.

Bertrand, Michel, "Familles, fidèles et réseaux: les relations sociales dans une société d'Ancien Régime", en José Luis Castellano e Jean-Pierre Dedieu (eds.), Réseaux, familles et pouvoirs dans le monde ibérique à la fin de l'Ancien Régime, Paris, CNRS Editions, 1998, páxs. 169-190.

Castro Díaz, Beatriz, "Familia, apadriñamento e onomástica na bisbarra eumesa: unha aproximación histórico-etnográfica (séculos XVII-XIX)", Cátedra: revista eumesa de estudios, 18 (2011), páxs. 413-474.

Castro Redondo, Rubén, Cartografia digital de Galicia en 1753. Jurisdicciones, provincias y Reino, Santiago de Compostela, Andavira, 2019.

Chacón Jiménez, Francisco, "Identidad y parentescos ficticios en la organización social castellana de los siglos XVI y XVII: el ejemplo de Murcia”, en Agustín Redondo (ed.), Les parentés fictives en Espagne (XVIe-XVIIe siècles), Paris, Publications de la Sorbonne, 1988, páxs. 37-50.

Domínguez Ortiz, Antonio;Camarero, Concepción, e Campos, Jesús (eds.), Vecindario de Ensenada 1759, Madrid, Centro de Gestión Catastral y Cooperación Tributaria, 1991.

Dubert García, Isidro, "Église, Monarchie, mariage et contrôle social dans la Galice rurale, XVIIIe-XIXe siècles”, Annales de démographie historique, 2 (2009), páxs. 101-121.

Dubert García, Isidro, Historia de la familia en Galicia durante la época moderna, 15501830: (estructura, modelos hereditarios y conflictividad), Sada, Edicións do Castro, 1992. 
Dubert García, Isidro, Los comportamientos de la familia urbana en la Galicia del Antiguo Régimen: el ejemplo de Santiago de Compostela en el siglo XVIII, Santiago de Compostela, Universidade de Santiago de Compostela, 1987.

Eiras Roel, Antonio, "El régimen señorial en Galicia a finales de la Edad Moderna: evaluación”, Obradoiro de Historia Moderna, 6 (1997), páxs. 7-46.

Fine, Agnès, "L'héritage du nom de baptême", Annales. Économies, Sociétés, Civilisations, 42, 4 (1987), páxs. 853-877.

Fine, Agnès, “Transmission des prénoms et parenté en Pays de Sault, 1740-1940”, en Jacques Dupâquier, Alain Bideau e Marie-Elizabeth Ducreux (eds.), Le Prénom: mode et histoire: entretiens de Malher 1980, Paris, École de Hautes Études, 1984, páxs. 108-125.

Ghirardi, Mónica,e Irigoyen López, Antonio, "Sacramento bautismal y padrinazgo de niños huérfanos. Textos eclesiástiscos postridentinos y prácticas en la Córdoba de mediados del siglo XIX", en Ana Cecilia Aguirre e Esteban Abalo (eds.), Representaciones sobre historia y religiosidad: deshaciendo fronteras, Rosario, Prohistoria Ediciones, 2014, páxs. 129-142.

Gómez Carrasco, Cosme Jesús,e García González, Francisco, "Parentesco ficticio y red social en la España meridional (Albacete, 1750-1808)", Popolazione e Storia, 1 (2008), páxs. 35-54.

González López, Tamara, Madriñas de brazo, padriños de pía: apadriñamento e bautismo no suroeste de Lugo (séculos XVI-XIX), Lugo, Asociación de Amigos do Mosteiro de Ferreira de Pallares, 2019.

González López, Tamara, El padrinazgo bautismal en la diócesis de Lugo (ss. XVI-XIX), Santiago de Compostela, Andavira, 2020

González López, Tamara, “Apadriñamento no Arciprestado de Bolaño”, Lucensia: miscelánea de cultura e investigación, vol. 27, núm. 53 (2016), páxs. 87-103.

Hanicot Bourdier, Sylvie Nathalie, "Ensayo sobre la religiosidad de una comunidad vasca en los siglos XVIII y XIX”, Procesos históricos: revista de historia, arte y ciencias sociales, 10 (2006), páxs. 1-15.

Irigoyen López, Antonio, "Ecclesiastical godparenthood in Early Modern Murcia”, en Guido Alfani e Vincent Gourdon (eds.), Spiritual Kinship in Europe, 1500-1900, London, Palgrave Macmillan, 2012, páxs. 74-95.

Lett, Didier, “Les frères et les soeurs, 'parentes pauvres' de la parenté", Medievales: Langue, textes, histoire, 54 (2008), páxs. 5-12.

Moratinos y Santos, Matías de, Constituciones Synodales del Obispado de Lugo. Compiladas, hechas y promulgadas por el Ilmo. Sr. D. Matías de Moratinos, Madrid, Imp. Ioseph Fernández de Buendía, 1675.

Pitt-Rivers, Julián, “L'elecció del padrí i l'elecció del nom: introducció a l'estudi del cas", Quaderns de l'Institut Català d'Antropologia, 5 (1984), páxs. 85-94.

Presedo Garazo, Antonio, "La preeminencia social de la nobleza gallega en el espacio sagrado durante los siglos XVI y XVII", Diversarum rerum: revista de los Archivos Catedralicio y Diocesano de Ourense, 9 (2014), páxs. 409-432.

Rey Castelao, Ofelia, "De la casa a la pila: hábitos y costumbres de bautismo y padrinazgo en Santiago de Compostela, siglos XVII-XVIII", en Inmaculada Arias de Saavedra Alías e Miguel Luis López Guadalupe Muñoz (eds.), Vida cotidiana en la Monarquía Hispánica: Tiempos y espacios, Granada, Universidad de Granada, 2015, páxs. 195-214. 
Rey Castelao, Ofelia, "Parrains et marraines en Galice aux XVIe-XIXe siècles: le diocèse de Saint-Jacques-de-Compostelle", en Guido Alfani, Vincent Gourdon e Isabelle Robin (eds.), Le parrainage en Europe et en Amérique. Pratiques de longue durée, XVIe-XXIe siècle, Bruxelles, Peter Lang, 2015, páxs. 69-98.

Rey Castelao, Ofelia, "La lucha por el agua en el país de la lluvia: Galicia, siglos XVI-XIX", Vínculos de Historia, 1 (2012), páxs. 45-72.

Rey Castelao, Ofelia,e Barreiro Mallón, Baudilio, "Apadrinar a un pobre en la diócesis de Santiago de Compostela, siglos XVII-XIX”, en María José Pérez Álvarez e Maria Marta Lobo de Araújo (eds.), La respuesta social a la pobreza en la Península Ibérica durante la Edad Moderna, León, Servicio de Publicaciones de la Universidad de León, 2014, páxs. 209-238.

Rodríguez Calleja, Jesús Emiliano, e Viera Ortega, Alfredo Jesús, "Padrinazgo y parentesco espiritual en Telde durante el siglo XVI", en XIV Coloquio de historia Canario-Americana, Las Palmas de Gran Canaria, Cabildo Insular de Gran Canaria, 2000, páxs. 948-974.

Rubio Velasco, Pamela, "La naturaleza del padrinazgo en la comarca de Ciudad Rodrigo (Salamanca) a lo largo del siglo XVIII", Tiempos modernos: Revista Electrónica de Historia Moderna, vol. 9, núm. 36, (2018), páxs. 264-279.

Saavedra Fernández, Pegerto, "La vida en los pazos gallegos: entre la civilidad y la rudeza", Chronica nova: Revista de historia moderna de la Universidad de Granada, 35 (2009), páxs. 163-191.

Saavedra Fernández, Pegerto, "La consolidación de las ferias como fiestas profanas en la Galicia de los siglos XVIII y XIX”, Sémata: Ciencias sociais e humanidades, 6 (1994), páxs. 279-296.

Sánchez Diego, Héctor Fernando, "Padrinazgo bautismal e inserción del foráneo en la Cantabria moderna", en Juan José Iglesias Rodríguez, Rafael M. Pérez García e Manuel F. Fernández Chaves (eds.), Comercio y cultura en la Edad Moderna, Sevilla, Universidad de Sevilla, 2015, páxs. 1667-1684.

Sánchez Diego, Héctor Fernando, "Patrones y prácticas asociadas al padrinazgo en un entorno rural: el valle de Iguña durante el s. XVII", Tiempos modernos: Revista Electrónica de Historia Moderna, vol. 8, núm. 29 (2014), páxs. 1-16.

Sobrado Correa, Hortensio, Las tierras de Lugo en la Edad Moderna: economía campesina, familia y herencia, 1550-1860, A Coruña, Fundación Pedro Barrié de la Maza, 2001.

Sobrado Correa, Hortensio, "Transformaciones agrarias, estrategias hereditarias y crecimiento demográfica en las tierras lucenses, 1750-1860", Obradoiro de Historia Moderna, 5 (1996), páxs. 7-40.

Zonabend, Françoise, "La parenté baptismale à Minot (Côte-d'Or)”, Annales. Économies, Sociétés, Civilisations, 33, 3 (1978), páxs. 656-676. 